\title{
RECENT STATE WIRETAP STATUTES: DEFICIENCIES OF THE FEDERAL COMMUNICATIONS ACT CORRECTED
}

Section 605 of the Federal Communications Act criminally proscribes unauthorized interception and divulgence of telephone communications. ${ }^{1}$ Although devitalized by lax enforcement and tenuous judicial construction, this section has been the major curb on wiretap activity since its enactment in 1934. ${ }^{2}$ State legislatures, reluctant to renounce an effective police technique,

1. 48 StAT. 1103 (1934), 47 U.S.C. $\S 605$ (1952). This section is the first federal statute seeking to regulate wiretapping on a permanent basis. At common law, eavesdropping was an indictable offense. 2 Wharton, Criminal Law $\S 1718$ (12th ed. 1932). But prior to $\$ 605$, the only federal attempt to prohibit wiretapping was a World War I statute which expired on governmental restoration of seized telephone and telegraph companies. Act of Oct. 29, 1918, c. 197, 40 Stat. 1017. From 1918 to 1934, federal wiretap policies were determined solely by the Attorney General and changed with appointments. See Donnelly, Comments and Caveats on the Wire Tapping Controversy, 63 YALE L.J. 799 (1954) (hereinafter cited as Donnelly, Comments and Caveats); Rogers, The Case for Wire Tapping, 63 Y ALE L.J. 792 (1954). On the particular needs to which the Communications Act was a response, see Benanti v. United States, 355 U.S. 96, $104 \&$ n.14 (1957).

The consent of the sender will validate interception and divulgence. 48 Stat. 1103 (1934), 47 U.S.C. \$ 605 (1952) ; Goldstein v. United States, 316 U.S. 114, 121 (1942); United States v. Gruber, 123 F.2d 307 (2d Cir. 1941). Normally, each party to a call is both sender and receiver. United States v. Polakoff, 112 F.2d 888, 889 (2d Cir.), cert. denied, 311 U.S. 653 (1940) ; United States v. Hill, 149 F. Supp. 83, 84 \& n.1 (S.D.N.Y. 1957) (contrary authority collected and rejected). But see Rathbun v. United States, 355 U.S. 106 (1957). But a receiver who answers without referring to the sender's message or without speaking at all may not be a sender. People v. Kelley, 22 Cal. 2d 169, 137 P.2d 1, cert. denied, 320 U.S. 715 (1942).

Interception and divulgence may also be valid if effected to administer other sections of the act. See 48 STat. 1103 (1934), 47 U.S.C. $\$ 605$ (1952) ; cf. United States v. Sugden, 226 F.2d 281 (9th Cir.), aff'd per curriam, 351 U.S. 916 (1955) (permissible to monitor radio station to prevent unauthorized operation).

To protect both parties, the Federal Communications Commission requires that all interstate tapping be accompanied by regular tone warnings. Use of Recording Devices in Connection With Telephone Service, Order of the Federal Communications Commission, Docket No. 6787, May 20, 1948. But this requirement has often been disregarded. Westin, The Wire-Tapping Problem: An Analysis and a Legislative Proposal, 52 Colum. L. Rev. 165, 184 (1952) (hereinafter cited as Westin, Analysis and Proposal); cf. United States v. Stephenson, 121 F. Supp. 274 (D.D.C.), appeal dismissed, 223 F.2d 336 (D.C. Cir. 1954).

2. Only one prosecution has been brought under $\S 605$ in the past twenty-four years. See United States v. Gruber, 39 F. Supp. 291 (S.D.N.Y.), aff'd, 123 F.2d 307 (2d Cir. 1941). See also Donnelly, Conments and Caveats, at 802 . The arrest of Gruber, a private citizen, occurred during a brief period in 1941 when the Justice Department adopted a strict view of the act. Fairfield \& Clift, The Wiretappers, Reporter Magazine, Dec. 23, 1952, p. 12. Presumably, the section is not enforced because the Justice Department refuses to prosecute others for acts it performs regularly. Westin, Analysis and Proposal, at 169 \& n.18, 179; see Wolf v. Colorado, 338 U.S. 25, 42 (1949) (dissenting opinion; unreasonable to expect district attorney to prosecute associates for violation of Fourth 
have generally prohibited wiretapping only to the extent that it constitutes malicious mischief. ${ }^{3}$ Moreover, most states, even those with specific wiretap-

Amendment on search which he authorized); On Lee v. United States, 343 U.S. 747, 759 (1952) (dissenting opinion); Pound, Crimmnal Justice in America 186 (1930). Despite these flaws, $\S 605$ is stronger than most state wiretap statutes, see note 3 infra, and more effectively regulates the use of wiretap information, see notes 4,14 infra.

In the absence of effective federal or state sanctions, wiretapping is a widespread practice. Hoover, A Comment on the Article "Loyalty Among Government Employees," 58 Yale L.J. 401,405 (1949) ; Westin, Analysis and Proposal, at 165-72 \& n.5; Note, 61 Y ALE L.J. 1221 (1952). See also N.Y. Times, March 10, 1958, $\S$ L, p. 3, cols. 5-6 (wiretapping of reporters to discover leaks of government secrets to the press); Westin, Analysis and Proposal, at 187 \& n.107 (wiretapping in wartime). On the prevalence of private tapping, see Joint Legislative Committee To Study Illegal. Interception of Comarunications, Report 26-29 (N.Y. Legislative Doc. No. 53, March 1956) (hereinafter cited as N.Y. LEGISLATIVE REPORT). The assistance rendered government agents by telephone companies contributes to the frequency of wiretapping. See Hearings Before a Subcommittce of the Senate Committee on Interstate Commerce Pursuant to S. Res. 224, 76th Cong., 3d Sess. passim (1940).

Despite the amount of current tapping, advocates of increased safeguards for national security emphasize the need for more wiretapping and less restriction. See Rogers, supra note 1 , at 793; N.Y. Times, Dec. 15, 1957, \& E, p. 7, cols. 1-4; \& WrGMORE, EvidENCE $\S 2184 \mathrm{~b}$ (3d ed. 1940); Westin, Analysis and Proposal, at 175 \& n.55 (collecting articles); cf. Hcarings Before Subcommittee No. 2 of the Honse Committee on the Judiciary on H.I. Res. 283, 77th Cong., 2d Sess. 21 (1942) (remarks of Representative Hobbs). But Congress has been unable to agree on less stringent wiretap controls. Westin, Antalysis and Proposal, at 181 \& n.72; Lowenthal, The Federal Bureau of Investrgation 323-26 (1950) ; cf. N.Y. Times, Jan. 17, 1958, p. 1, cols. 3-4 (proposed law to overturn Benanti v. United States, 355 U.S. 96 (1957)).

For judicial constructions which have weakened the effect of $\S 605$, see notes 9,14 infra. See also Rosenzweig, The Law of Wire Tapping, 32 CoRneul L.Q. 514, 518-23 (1947); Westin, Analysis and Proposal, at 178-81; Wall Street Journal, May 10, 1957, p. 8 , cols. 1-2.

3. Only five states, including Pennsylvania and Illinois, see note 5 infra, expressly prohibit interception and disclosure. Of the nineteen states which have specific wiretap prohibitions, statutes or case law in five authorize police tapping, and the question is unsettled in four. Four other states have no statutory provision whatever. Another has an eavesdropping act; and four more forbid only divulgence by employees of communications companies. The remaining fifteen states simply rely on malicious mischief laws. Three of these laws expressly prohibit telephone companies from disclosing messages, and three apply only to telegraph messages. These malicious mischief statutes are totally inadequate to control wiretapping, since they only prohibit damage to utilities and equipment. N.Y. Legrstative Report app. B, 54-71; Rosenzweig, The Law of Wire Tapping, 33 CoRNELL L.Q. 71, 74 \& nn.178-82 (1947).

The recently enacted Oregon wiretap act, forbidding interception by any device without the consent of one participant, bears strong resemblance, particularly in its definitional sections, to the model act proposed by Professor Westin. The major difference is the Oregon law's failure specifically to proscribe divulgence. Compare ORE. Rev. STAT. $\$ \$ 165.535,165.540$ (1955), with Westin, Analysis and Proposal, at 200-08. For an example of the different results under similar state tapping statutes, see $i d$. at 183-84 (California and New York disagree on right of subscriber to tap his own wire).

For the view that states adopt more effective protections against wiretapping because of an increased concern with personal, nonproperty rights, see Rosenzweig, supra at 74. 
ping prohibitions, not only fail to prosecute offenders but admit illegally obtained communications in evidence. ${ }^{4}$ Recent adoption by Pennsylvania and Illinois of wiretap legislation broader and more stringent than section 605 , however, forecasts a conflict between federal and state interests disrupting the existing regulatory pattern. 5

4. Of the thirty-three states admitting wiretap evidence, thirteen have statutes making wiretapping illegal. In twelve jurisdictions illegally obtained evidence is inadmissible, and in three the issue remains unresolved. N.Y. LegrsLative RepoRT app. B, 54-71. A recent Texas law providing that all evidence obtained in violation of $\$ 605$ is inadmissible in Texas courts, Texas Code Crrur. Proc. art. 727A (Supp. 1954), is the only state utilization of that section as a standard of admissibility.

State prosecutions for wiretapping were rare before 1947, see Rosenzweig, supra note 3 , at 75 , and since then none has been reported.

5. The Illinois statute reads in part:

"Section 1. For the purposes of this Act:

" 'Electronic eavesdropping' means the use of any device employing electricity to hear or record, or both, all or any part of any oral conversation ... without consent of any party thereto, whether such conversation is conducted in person or by telephone....

"'Person' means any individual, firm or corporation, including but not by way of limitation, any law enforcement officer of this state or any municipality or other political subdivision thereof, or of the United States, whether or not within the course of his employment.

"'Eavesdropper' means any individual who operates or helps or participates in the operation of any device used in electronic eavesdropping.

"'Principal' means any person who employs another who, to the knowledge of the employer, used electronic eavesdropping in the course of such employment, or any person who knowingly derives any benefit or information by virtue of the electronic eavesdropping of another, or who directs another to use electronic eavesdropping on his behalf.

"Section 2. Electronic eavesdropping is prohibited and any violation of this Act is a misdemeanor and any person convicted thereof shall be fined not less than one hundred dollars nor more than one thousand dollars, or, if an individual, sentenced to not less thau ten days nor more than one year in the county jail or both.

"Section 3. Any or all parties to any conversation upon which electronic eavesdrupping is practiced contrary to this Act shall have the following rights:

"(a) To an injunction by any court of competent jurisdiction prohibiting further electronic eavesdropping by the individual eavesdropper and by or on behalf of his principal, or either.

"(b) To all actual damages against the eavesdropper or his principal or both.

"(c) To any punitive damages which may be awarded by the court or by a jury.

"(d) To all actual damages against any landlord, owner or building operator, or any common carrier by wire who aids, abets or knowingly permits the electronic eavesdropping concerned.

"(e) To any punitive damages which may be awarded by the court or by a jury against any landlord, owner or building operator, or common carrier by wire who aids, abets or knowingly permits the electronic eavesdropping concerned.

"(f) Any evidence obtained in violation of this Act is not admissible in any civil or criminal trial, or any administrative or legislative inquiry or proceeding, nor in any grand jury proceedings.

"Section 4. Any person who uses or divulges any information which he knows or reasonably should know was obtained by illegal electronic eavesdropping shall be guilty of a misdemeanor and shall be subject to the penalties for violation of this Act provided 
The Pennsylvania and Illinois acts are apparently designed to remedy the ineffectual wiretap control of section $605 .^{6}$ While lower federal courts have consistently construed the federal act to prohibit only interception coupled with divulgence, ${ }^{7}$ the state laws further condemn interception alone. ${ }^{8}$ Similar-

in Section 2 and shall be subject to damages and other remedies provided in Section 3 of this Act.

"....

"Section 6. This Act shall be deemed severable and if any section, paragraph, sentence or part thereof ever be held invalid or unenforceable, such decision shall not in any way affect the remaining portions of this Act." Illinois House Bill \#1210, reported June 19, 1957. Although the Illinois act became law in 1957, a formal citation is unavailable. Its passage is reported in American Civil Liberties Union Weekly Bulletin, No. 1918, Oct. 7, 1957, p. 2.

The Pennsylvania act provides in part:

"No person shall intercept a communication by telephone or telegraph without permission of the parties to such communication. No person shall install or employ any device for overhearing or recording communications passing through a telephone or telegraph line with intent to intercept a communication in violation of this act. No person shall divulge or use the contents or purport of a communication intercepted in violation of this act. Whoever wilfully violates or aids, abets or procures a violation of this act is guilty of a misdemeanor, and shall be punishable by imprisonment of not more than one year, or by fine of not more than five thousand dollars $(\$ 5000)$, or both, and shall be liable to any person whose communication is unlawfully intercepted or divulged for treble the amount of any damage resulting from such unlawful interception, divulgence or use, but in no event less than one hundred dollars $(\$ 100)$ and a reasonable attorney's fee. The term 'person' includes natural persons, business associations, partnerships, corporations, or other legal entities, and persons acting or purporting to act for, or in behalf of, any government or subdivision thereof, whether Federal, State or local. The term 'divulge' includes divulgence to a fellow employe [sic] or official in government or private enterprise or in a judicial, administrative, legislative or other proceeding. Except as proof in a suit or prosecution for a violation of this act, no evidence obtained as a result of an unlawful interception shall be admissible in any such proceeding ..." PA. Stat. AnN. tit. $15, \S 2443$ (Supp. 1957).

6. These laws are specifically applicable to federal agents; they clearly prohibit intercoption itself; they provide civil remedies against wiretappers; and they expressly declare wiretap evidence inadmissible. In each state, previous wiretapping laws were patently inadequate. Illinois had only a malicious mischief statute coupled with a proscription against tapping for otherwise illegal purposes such as bribery or blackmail. ILr. Stat. ANN. ch. 134, $\$ \$ 15$ (a), 16 (Smith-Hurd 1936). And Pennsylvania prohibited only malicious mischief and divulgence by company employees. PA. Stat. AnN. tit. 18, \$§ 4688, 4916 (1939). Moreover, the Pennsylvania supreme court held $\S 605$ inapplicable to state officers acting in connection with state crimes or divulging to state courts. Commonwealth v. Chaitt, 380 Pa. 532, 112 A.2d 379 (1955).

7. The Attorney General announced conjunctive reading of $\S 605$ in a letter to the House Judiciary Committee. Hcarings Before Subcommittee No. 1 of the Hotse Committce on the Indiciary on H.R. 2266 and H.R. 3099, 77th Cong., 1st Sess. 18 (1941.). This interpretation has frequently been criticized. See, e.g., S. REP. No. 2700, 81st Cong., 2d Sess. 5 (1950); Donnelly, Comments and Caveats, at 800-03. The Treasury Department, in contrast, at least says that interception is itself prohibited. Id. at $802 \&$ n.18. Nevertheless, lower federal courts have accepted the Justice Department's reading of $\S 605$. See United States v. Coplon, 91 F. Supp. 867, 871 (D.D.C. 1950), rev'd on other grounds, 191 F.2d 749 (D.C. Cir.), cert. denied, 342 U.S. 926 (1951) ; United States v. Sullivan, 1.16 
ly, section 605 is generally restricted to devices requiring physical contact with the telephone system, ${ }^{9}$ but interception under the state statutes comprehends any electronic eavesdropping. ${ }^{10}$ And where the federal law permits tapping if authorized by the sender, ${ }^{11}$ the state acts require the consent of both parties to the communication. ${ }^{12}$ In addition, the Pennsylvania and Illinois statutes are specifically applicable to federal as well as state officers. ${ }^{13}$

Prosecution of United States officers under the Pennsylvania and Illinois laws would curtail current federal uses of illegally obtained wiretap informa-

F. Supp. 480 (D.D.C. 1953) : United States v. Goldstein, 120 F.2d 485, 490 (2d Cir. 1941), aff'd on other grounds, 316 U.S. 114 (1942) (dictum). But the Supreme Court has carefully avoided ruling on the question. See Benanti v. United States, 355 U.S. 96, 100 n.5 (1957) ; Rathbun v. United States, 355 U.S. 107, 108 \& n.3 (1957). This reticence has only given permissive effect to the justice department interpretation. One commentator suggests that the Court's indecision is based on its inability to decide on a solution to the dilemma of wiretapping. Westin, Analysis and Proposal, at 179.

8. See statutes quoted note 5 supra.

9. See Goldman v. United States, 316 U.S. 129 (1942) (detectaphone against wall of room in which conversation occurred not interception); Rayson v. United States, 238 F.2d 160 (9th Cir. 1956) (listening on extension of receiver's ghone not interception); Rathbun v. United States, 355 U.S. 107 (1957) (listening from adjoining room by means of mechanical device not interception); Billeci v. United States, 184 F.2d 394 (D.C. Cir.), reversing on other grounds United States v. Lewis, 87 F. Supp. 970 (D.D.C. 1950) (no interception where federal agent answered phone and took message in gambling establishment) ; United States v. Guller, 101 F. Supp. 176 (E.D. Pa. 1951) (interception must be accomplished by some apparatus interposed in transmitting mechanism); cf. United States v. Yee Ping Jong, 26 F. Supp. 69 (W.D. Pa. 1939). But see United States v. Polakoff, 112 F.2d 888 (2d Cir.), cert. denied, 311 U.S. 653 (1940) (interception present when any person listens to telephone call without consent of both conversants); United States v. Gruber, 123 F.2d 307 (2d Cir. 1941) (same); United States v. Stephenson, 121 F. Supp. 274 (D.D.C.), appeal dismissed, 223 F.2d 336 (D.C. Cir. 1954) (same) ; Reitmeister v. Reitmeister, 162 F.2d 691 (2d Cir. 1947) (existing lead from main wire no different from tap into wire); United States v. Hill, 149 F. Supp. 83 (S.D.N.Y. 1957) (use of microphone is interception whether it touched or was only near phone); United States v. Copion, 88 F. Supp. 921 (S.D.N.Y. 1950) ; Note, 53 Mick. L. REv. 623 (1955). See also Nardone v. United States, 308 U.S. 338, 340 (1939) (refusal to allow indirect circumvention of $\S 605$ ).

Similar technical distinctions are drawn in state cases. See California v. Malotte, 46 Cal. 2d 59, 292 P.2d 517 (1956) (recording conversation by induction coil operating at receiver's telephone not interception); California v. Lawrence, 149 Cal. App. 2d 435, 308 P.2d 821 (1957) (no interception where police officer listened to amplifier attached to receiver by extension cord). See also \& WIGMoRe, EvIDENCE $\$ 2184 c$ (Supp. 1957) (use of amplifier and dictaphone approved).

The definition which requires physical contact with the telephone system has been criticized as confusing, impractical and obsolescent. See Westin, Analysis and Proposal, at 197-200 (including analysis of different mechanisms employed); Mellin, I Was a IVire Tapper, Saturday Evening Post, Sept. 10, 1949, p. 57; cf. Berger, Tapping the Wires, The New Yorker, June 18, 1938, p. 41.

10. See statutes quoted note 5 supra.

11. See note 1 supra.

12. See statutes quoted note 5 supra.

13. Ibid. 
tion. Although generally neither admitted in the federal courts nor allowed as a lead to admissible evidence, ${ }^{14}$ such information has been utilized to encourage confessions, ${ }^{15}$ to refresh a witness's recollection before he testifies, ${ }^{16}$ and against any person not a party to the communication. ${ }^{17}$ But even such accepted uses of wiretap information constitute illegal divulgence. ${ }^{18}$ Nevertheless, no federal officer has ever been prosecuted for violation of section $605 .^{19}$ Furthermore, since 1941 the Department of Justice, considering itself a unity for such

14. Before $\S 605$, evidence obtained by wiretapping was admissible in the federal courts. See Bushouse v. United States, 67 F.2d 843 (6th Cir. 1933); Foley v. United States, 64 F.2d 1 (5th Cir.), cert. denied, 289 U.S. 762 (1933); Kerns v. United States, 50 F.2d 602 (6th Cir. 1931).

Even after enactment of the Communications Act, wiretap evidence was admitted in the federal courts. Beard v. United States, 82 F.2d 837 (D.C. Cir.), cert. denied, 298 U.S. 655 (1936). However, in 1938 the Supreme Court reversed a criminal conviction because the prosecution's evidence was illegally obtained by wiretapping. Nardone v. United States, 302 U.S. 379 (1937). Subsequently, it extended this application of $\S 605$ to evidence procured through knowledge gained from wiretapping, Nardone v. United States, 308 U.S. 338 (1939), and to intrastate as well as interstate communications, Weiss v. United States, 30S U.S. 321 (1939). The admissibility of illegal evidence in state courts is a matter of state law despite the federal bar. Wolf v. Colorado, 338 U.S. 25 (1949). Only in 1957 did the Court finally proscribe the use in federal courts of evidence obtained by state officials in violation of $\S 605$. Benanti v. United States, 355 U.S. 96 (1957).

The Nardone cases have been sharply criticized as judicial legislation. See, e.g., Notes, 6 Geo. Wash. L. Rev. 326 (1938), 53 Harv. L. Rev. 863 (1940), 34 Ill. L. Rev. 758 (1940), 16 Texas L. Rev. 574 (1938), 86 U. Pa. L. Rev. 436 (1938). But over twenty years of unsuccessful congressional attempts to amend the statute add strength to the Court's construction. See note 7 supra. And states can still use or prohibit wiretap evidence in their courts as they choose. Schwartz v. Texas, 344 U.S. 199 (1952).

The exclusion of "tainted" evidence evokes the serious problem of distinguishing evidence produced by wiretapping from evidence otherwise procured. See, Rosenzweig, sutpra note 2 , at 540 . The burden of proof on the party seeking to exclude wiretap evidence is considerable, see Note, 61 Y ALE L.J. 1221 (1952), since the mere fact of tapping will not taint evidence, Coplon v. United States, 191 F.2d 749 (D.C. Cir. 1951), cert denied, 342 U.S. 926 (1952). Consequently, some courts shift the burden to the prosecution. See United States v. Goldstein, 120 F.2d 485, 488 (2d Cir. 1941), aff'd, 316 U.S. 114 (1942).

15. Coplon v. United States, \&S F. Supp. 921 (S.D.N.Y. 1950).

16. See Monroe v. United States, 234 F.2d 49 (D.C. Cir.), cert. denied, 352 U.S. 873 (1956).

17. Goldstein v. United States, 316 U.S. 114 (1942), affirming 120 F.2d 485 (2d Cir. 1941). The Court based its holding on the doctrine permitting the introduction in federal courts of evidence obtained by an illegal search and seizure so long as the defendant is not the subject of the illegal search. Id. at 121 \& n.12. See also Weeks v. United States, 232 U.S. 383 (1914). But see Goldstein v. United States, supra at 127 (dissenting opinion; analogy to search and seizure unwarranted since rule against inadmissibility is "not a remedy for the sender ... [but] the obedient answer to the Congressional command that society shall not be plagued with such practices as wire-tapping") ; cf. Comment, 57 Colum. L. REv. 1159, 1161 n. 30 (1957).

18. See Goldstein v. United States, supra note 17; United States v. White, 228 F.2d 832 (7th Cir. 1956); State v. Steadman, 216 S.C. 579,59 S.E.2d 168, cert. denied, 340 U.S. 850 (1950).

19. See note 2 supra. 
purposes, has consistently declared that divulgence to a superior within the department is not illegal. ${ }^{20}$ Vigorous application of the state acts, disallowing interception unaccompanied by divulgence, would jeopardize these long-established federal practices.

Enforcement of the state statutes against federal officers, however, may be unconstitutional. The supremacy clause of the United States Constitution precludes state regulation of federal instrumentalities acting in pursuance of valid federal law. ${ }^{21}$ Thus geared to federal authority, the clause would not block state prosecution of a federal agent who violated both section 605 and a state wiretap statute. ${ }^{22}$ When the tapping condemned by state law was legal

20. This view was first enunciated by Attorney General Biddle. N.Y. Times, Oct. 9, 1941, p. 4, col. 2; see Donnelly, Comments and Caveats, at 801. For the circumstances surrounding this declaration, see Fairfield \& Clift, supra note 2, p. 13.

The Department has also declared that $\S 605$ was only intended to eliminate use of illegal wiretapping information for personal gain, not aid of law enforcement. Although the majority of the Court in Goldstein v. United States, 316 U.S. 114 (1942), refused to rule on this contention, $i d$. at 122 , the dissent emphatically rejected it, id. at 125 .

21. See U.S. Const. art. VI, cl. 2; PUC v. United States, 78 Sup. Ct. 446 (1958); Mayo v. United States, 319 U.S. 441, 445 \& n.5 (1943) (disallowing inspection fees imposed by state on federally owned and distributed fertilizer; collecting cases); Pacific Coast Dairy, Inc. v. Department of Agriculture, 318 U.S. 285, 294 \& nn.11-13 (1943) (collecting cases); Dowling, Cases on Constitumional Law 229-32 (5th ed. 1954) (collecting cases). For collection and analysis of earlier cases, see Powell, Supreme Court Decisions on the Commerce Clause and State Police Pozver 1910-1914, 21 Coluar. L. Rev. 737, 22 id. at 133 (1921-22).

22. A federal officer acting under color of authority or in pursuit of his duties is not immune from conviction for violation of state law if his conduct also contravenes the laws of the United States. See Johnson v. Maryland, 254 U.S. 51, 56 (1920) (dictum); Ohio v. Thomas, 173 U.S. 276, 283 (1899) (dictum); In re Neagle, 135 U.S. 1, 68, 75 (1890) (dictum); United States v. Hart, 1 Peters' Cir. Ct. 390 (1817) (dictum); Obstruction of Mail Carriers, 5 Ops. ATT'y GEN. 554, 555-56 (1852). Alleged action under color of authority, however, will justify removal of a state prosecution of a federal agent from a state to a federal court. 28 U.S.C. \& 1442 (1952) ; MOORE, JUDICTAL CODE 253-57 (1949) ; Ex parte Shockley, 17 F.2d 133, 137 (N.D. Ohio 1926) (collecting cases) ; Norfolk v. McFarland, 143 F. Supp. 587 (E.D. Va. 1956) ; Colorado v. Maxwell, 125 F. Supp. 18 (D. Colo. 1954) ; Logemann v. Stock, 81 F. Supp. 337 (D. Neb. 1949) ; Potts v. Elliott, 61 F. Supp. 378 (E.D. Ky. 1945). See also Ex parte Dierks, 55 F.2d 371 (D. Colo. 1932). For a thorough historical appraisal of the removal process, see Strayhorn, The Immunity of Federal Officers From State Prosecutions, 6 N.C.L. Rev. 124 (1927).

Prosecutions transferred to the federal district court under $\$ 1442$ proceed as if in the state court from which removed. See Tennessee v. Davis, 100 U.S. 257 (1879); Atlantic C.L.R.R. v. Georgia, 234 U.S. 280 (1914); Strayhorn, supra at 134. See also Ponzi v. Fessenden, 258 U.S. 254 (1922) (where both federal and state governments have criminal charges against individual, whichever exercises jurisdiction first continues action to completion).

Removal presumably avoids a possibly hostile state forum. Gordon v. Longest, 41 U.S. (16 Pet.) 63 (1842) ; Bishop, The Jurisdiction of State and Federal Courts Over Fcderal Officers, 9 CoLum. L. REv. 397 (1909) ; Crimmins, Remozal of Indictments by Fideral Officers as an Invasion of States' Rights, 8 Notre Dane Law. 354 (1933). For criticism of this purpose and its effects, see Strayhorn, supra at 145 . 
under the federal act, on the other hand, application of the state statute would be unconstitutional. ${ }^{23}$ Construing state law as inapplicable to federal officers acting legally by federal standards would avoid invalidation of those sections specifically directed against federal agents. Although such construction by the state courts would bind federal judges, ${ }^{24}$ the explicit and unconfined applicability of the Pennsylvania and Illinois acts to United States officers may render a similar federal interpretation difficult in the absence of prior state warrant. ${ }^{25}$

A recent Supreme Court decision, moreover, may be interpreted to hold that section 605 excludes all state wiretapping regulation. Benanti v. United States prohibited the use in federal courts of wiretap evidence obtained by New York state agents in compliance with New York law. ${ }^{26}$ Since section 605 is applicable to both interstate and intrastate communications, ${ }^{27}$ the Court reasoned,

23. See Johnson v. Maryland, supra note 22; Ohio v. Thomas, supra note 22; In re Neagle, supra note 22.

24. Mínnesota ex rel. Pearson v. Probate Court, 309 U.S. 270, 273 (1940) (interpretation of Minnesota psychopathic offender statute by the highest state court binds the Supreme Court; collecting cases).

25. See Lambert v. California, 355 U.S. 225 (1957) (Los Angeles convicted-felon registration ordinance unconstitutional since willfullness not an element of violation either by terms or by construction).

Since prosecution of a federal officer under either state statute would be immediately removable to the federal courts, see note 22 supra, obtaining prior state declaration of inapplicability to federal officers who have not violated $\S 605$ may necessitate resort to an action for declaratory judgment by a state officer ordered to engage in wiretap activity. The Illinois Declaratory Judgments Act specifically approves construing state laws when an actual controversy exists. ILL. Stat. ANN. c. 110, § 57.1 (Smith-Hurd 1957). Illinois courts have rendered declaratory judgments where rights are or are about to be affected by a statute's enforcement. Note, 33 ILI. L. Rev. 478, 480 (1938) (collecting cases). See, generally, United Pub. Workers v. Mitchell, 330 U.S. 75 (1947) (disallowing federal declaratory judgment because threatened enforcement of state law for violation not specifically alleged). Pennsylvania has adopted the Uniform Declaratory Judgments Act, PA. Srur. ANn. tit. 12, $\$ \$ \$ 31-46$ (Supp. 1957), which does not specifically provide for statutory construction. Case law has, however, permitted it. See Taylor v. Haverford Township, $299 \mathrm{~Pa} .402$, 149 Atl. 639 (1930). But Pennsylvania courts also dismiss declaratory actions which constitute no more than requests for advisory opinions. See Reese v. Adamson, 297 Pa. 13, 146 Atl. 262 (1929) ; Ladner v. Siegel, 294 Pa. 368, 144 Atl. 274 (1928). An actual controversy between a state offcer ordered to tap in violation of state law and the state attorney general could thus satisfy statute and precedents in both Pennsylvania and Illinois.

26. 355 U.S. 96 (1957). Positing the exclusionary rule as only a sanction against wverzealous enforcement of federal laws, the Second Circuit had admitted the wiretap evidence obtained by state officers without intent to transfer it to federal agents. United States v. Benanti, 244 F.2d 389, 390, 393 (2d Cir. 1957); see Comment, 57 Colum. L. Rev. 1159 (1957) (approving the unequivocality of the holding though questioning the result); 106 U. PA. L. Rev. 314 (1957); 43 VA. L. REv. 944 (1957) (approving the decision's consistency with existing law).

27. Weiss v. United States, 308 U.S. 321 (1939); Massengale v. United States, 240 F.2d 781, 782 (6th Cir. 1957); United States v. White, 228 F.2d 832 (7th Cir. 1956); United States v. Sugden, 226 F.2d 281 (9th Cir. 1955), aff'd per curiam, 351 U.S. 916 (1956) ; United States v. Lipinski, 151 F. Supp. 145 (D.N.M. 1957) ; United States v. Gris, 
Congress can clearly proscribe all state-authorized wiretapping. ${ }^{28}$ Unless the federal act is so construed, it continued, New York law would jeopardize the protection afforded by Congress. ${ }^{29}$ The Court also found that Congress did not intend to permit state law to "contradict" section 605 or its policy. ${ }^{30}$ Read literally, this assertion could imperil state laws extending protection from wiretapping beyond the federal statute. But since the tenor of the opinion is otherwise confined to preserving the safeguards adopted by federal law, such an implication was probably unintended.

Traditional criteria for determining congressional intent to pre-empt fields otherwise subject to state regulation also suggest that section 605 does not bar the Pennsylvania and Illinois statutes. Before such intent is found, a comprehensive scheme of federal control linked with a dominant federal interest must be established. ${ }^{31}$ Although the Communications Act embraces both the

146 F. Supp. 293 (S.D.N.Y. 1956). Presumably, the indiscriminate nature of wiretapping precludes separating interstate from intrastate communications. See Westin, Analysis and Proposal, at 176.

28. 355 U.S. at 105 ; In re Interception of Telephone Communications, 26 U.S.L. WEEK 2331 (N.Y. Sup. Ct. Jan. 2, 1958); Burack v. State Liquor Authority, 26 U.S.L. WeEk 1147 (E.D.N.Y. March 12, 1958) ; see N.Y. World-Telegram \& Sun, April 11, 1958, p. 30, cols. $1-4$; cf. Weiss v. United States, supra note 27, at 328-29.

29. 355 U.S. at $104-05$.

30. Id. at 105-06: "Congress ... did not mean to allow state legislation which would contradict that section [605] and that policy." Certainty as to the underlying policy of $\S 605$ is not easily achieved. Eight years after its enactment, the Court stated that the section was designed to protect the means rather than secrecy of communication. Goldman v. United States, 316 U.S. 129, 133 (1942). This view parallels statements that the purpose of the Communications Act was to extend the jurisdiction of the existing Radio Commission to telecommunications. See Weiss v. United States, 308 U.S. 321, 328 (1939); H.R. Rep. No. 1850, 73d Cong., 2d Sess. 3 (1934) ; 78 Cong. Rec. 8822 (1934). But popular concern was with the intrusion on privacy which Mr. Justice Brandeis had depicted in his dissent in Olmstead v. United States, 277 U.S. 438, 478 (1928). For a thorough survey of newspaper opinion in the early postwar years, see Westin, Analysis and Proposal, at 189-92. Lower federal courts have reflected this concern by stating that $\S 605$ was intended to safeguard the individual. United States v. Hill, 149 F. Supp. 83 (S.D. N.Y. 1957) ; United States v. Coplon, 91 F. Supp. 867 (D.D.C. 1950). Nevertheless, the Supreme Court recently reaffirmed the "protection of the system" position. See Rathbun v. United States, 355 U.S. 107 (1957).

31. See Rice v. Santa Fe Elevator Corp., 331 U.S. 218, 229-31 (1947) ; Hines v. Davidowitz, 312 U.S. 52, 66-67 \& nn. 18 \& 19 (1941) (collecting cases); United States v. Darby, 312 U.S. 100, 118-20 \& n.3 (1941) (collecting cases); Pennsylvania v. Nelson, 350 U.S. 497 (1956).

However, the simplicity of this dual test belies the real problem. State courts have often held that an explicit, clear or obvious congressional intent to pre-empt is necessary to void state law. McQuay, Inc. v. United Automobile Workers, CIO, 245 Minn. 274, 281-82, 72 N.W.2d 81, 86 (1955) ; People v. Knapp, 4 Misc. 2d 449, 157 N.Y.S.2d $\$ 20$ (N.Y. County Ct. Gen. Sess. 1956) ; Commonwealth v. Chaitt, 380 Pa. 532, 539, 112 A.2d 379, 383 (1955) ; Commonwealth v. DiMeglio, 179 Pa. Super. 472, 117 A.2d 767 (1955) ; First Nat'1 Sav. Foundation v. Samp, 274 Wis. 118, 138, 80 N.W.2d 249, 261 (1956). This view has pervaded many Supreme Court opinions. See California v. Zook, 336 U.S. 725, 733 (1949) ; Parker v. Brown, 317 U.S. 341 (1943), 27 Minn. L. Rev. 468; Apex Hosiery Co. 
requisite breadth and federal concern, ${ }^{32}$ the Supreme Court has differentiated the thrust of section 605 from that of the remainder of the act. ${ }^{33}$ Accordingly, the act's general pre-emptive effect need not be imputed to the wiretap section. ${ }^{34}$ Evaluated independently, the area of wiretap control does not reveal a federal interest so dominant as to exclude state action which does not derogate from congressional proscriptions. The federal courts have held that section 605 was designed to protect the integrity of communications systems rather than the privacy of communicants. ${ }^{35}$ Communications systems, inevitably geared to interstate commerce, are obviously a subject of paramount federal interest. ${ }^{36}$ But the primary effect of the Pennsylvania and Illinois statutes is to extend to individuals a measure of privacy unattained under the federal act. ${ }^{37}$ Since security from wiretap interference is not guaranteed by the United States Constitution, ${ }^{38}$ protecting citizens from invasions considered unwarranted

v. Leader, 310 U.S. 469 (1940); Steffen, Labor Activities in Restraint of Trade: The Apcx Cases, 50 YaLE L.J. 787 (1941) ; International Shoe Co. v. Pinkus, 278 U.S. 261 (1929) ; cf. Illinois Natural Gas Co. v. Central Illinois Pub. Serv. Co., 314 U.S. 498, 508-10 (1942). But since congressional intent to pre-empt is rarely stated explicitly, the extent of the regulatory measure, see Parker v. Brown, sitpra at 363; California v. Thompson, 313 U.S. 109, 113-14 (1941), and the public need for uniformity, Garner v. Teamsters Union, AFL, 346 U.S. 485, 500-01 (1953) ; Southern Ry. Co. v. Railroad Comm'n, 236 U.S. 439,446 (1915), become crucial. Nevertheless, California v. Zook, supra at 732-33, criticizes findings of pre-emption in the absence of specifically announced legislative intent. See also PUC v. United States, 78 Sup. Ct. 446, 454 (1958) (dissenting opinion). For a discussion of the theory and case law of pre-emption, see Note, 60 HARv. L. Rev. 262 (1946); Powell, supra note 21.

32. Benanti v. United States, 355 U.S. 96, 104 \& n.14 (1957) ; NBC v. United States, 319 U.S. 190 (1943), affirming 47 F. Supp. 940 (S.D.N.Y. 1942) (Communications Act pre-empts the field of radio broadcasting regulation); Allen B. Dumont Laboratories v. Carroll, 184 F.2d 153 (3d Cir. 1950), cert. denied, 340 U.S. 929 (1951) (Communications Act pre-empts interstate television regulation); McCaw v. Commissioner, 40 Hawaii 121 (Hawaii Cir. 1953) ; cf. FCC v. Pottsville Broadcasting Co., 309 U.S. 134 (1940).

33. See Weiss v. United States, 308 U.S. 321, 329 (1939).

34. Ibid. The Court found $\S 605$ equally applicable to intrastate and interstate communications, while recognizing that the body of the act comprehended only interstate and foreign communications. This finding, based on the more inclusive language of $\S 605$, may allow a similar differentiation of that section from the rest of the act for purposes of assessing pre-emptive effect. See also Schwartz v. Texas, 344 U.S. 199, 203 (1952) (Congress did not intend $\S 605$ to supersede state rules of evidence).

35. Goldman v. United States, 316 U.S. 129, 133 (1942); Diamond v. United States, 108 F.2d 859, 860 (6th Cir. 1938); see Rathbun v. United States, 355 U.S. 107, 110 (1957).

36. See cases cited note 35 supra.

37. "We considered the passage of the wiretap bill a great victory for civil liberties. . . Pennsylvania has always admitted illegally obtained evidence. One of the purposes of this act was to exclude such evidence from the state courts." Letter from Lois G. Forer, Deputy Att'y Gen. of Pennsylvania, to the Yale Law Journal, March 7, 1958, on file in Yale Law Library. See also American Civil Liberties Union Weekly Bulletin, No. 1918, Oct. 7, 1957, p. 2; N.Y. Times, May 21, 1958, § L, p. 30, cols. 5-6.

38. Olmstead v. United States, 277 U.S. 438 (1928). For discussion of Olmstead, see Notes, 38 Yale L.J. 77 (1928), 27 Mich. L. Rev. 78 (1928), 27 Mich. L. Rev. 927 (1929), 77 U. PA. L. Rev. 139 (1928), 65 U.S.L. Rev. 56 (1931), 15 VA. L. Rev. 62 (1928). 
seems a proper area for state regulation. ${ }^{39}$ A contrary conclusion would posit the apparent anomaly that the federal statutory aim of protecting communications systems prevents states, desiring to safeguard communicants, from requiring of their officers less wiretap activity than that permitted federal agents by Congress. ${ }^{40}$

Even were section 605 to exclude the Pennsylvania and Illinois acts, the states would not necessarily be foreclosed from adopting valid legislation of similar effect. Within the bounds of the Fourteenth Amendment, the states retain exclusive authority to determine rules of evidence applicable in their judicial systems. ${ }^{41}$ State legislatures may prohibit the use in court of evidence obtained by wiretapping. ${ }^{42}$ Moreover, they may impose criminal liability upon state officers for gathering evidence known to be inadmissible. For the concept of federalism must at the very least permit each state to restrict the administrative actions of its own officers. Admittedly, such state action, unlike the Pennsylvania and Illinois statutes, would not reach federal officers and private citizens. But civil suits vindicating state-created substantive rights are frequently maintained in areas occupied by the federal government for regulatory purposes so long as Congress has not furnished substitute federal actions. ${ }^{43}$ Suits for defamation occurring on interstate television programs, for example, are permitted although the Communications Act has been interpreted to ex-

39. See U.S. Const. amend. $X$. The police power is reserved to the states, United States v. Renken, 55 F. Supp. 1 (W.D.S.C. 1944), aff'd sub nom. Old Monastery Co. v. United States, 147 F.2d 905 (4th Cir.), cert. denied, 326 U.S. 734 (1945) ; State v. Whitaker, 228 N.C. 352 , 45 S.E.2d 860 (1947), aff'd, 335 U.S. 525 (1949); see United States v. Constantine, 296 U.S. 287 (1935); United States v. Kesterson, 296 U.S. 299 (1935), and is only limited by the Fourteenth Amendment and the Bill of Rights, Eastman v. Yellow Cab Co., 173 F.2d 874 (7th Cir. 1949); Siegel v. Ragen, 180 F.2d 785 (7th Cir.), cert. denied, 339 U.S. 990 (1950); see AFL v. Swing, 312 U.S. 321 (1941). Public health, safety and morals are proper subjects for exercise of the police power. Berman v. Parker, 348 U.S. 26 (1954); First Nat. Ben. Soc. v. Garrison, 58 F. Supp. 972 (S.D. Cal. 1945), aff'd per curiam, 155 F.2d 522 (9th Cir. 1946) (collecting cases).

40. Congressional intent to interfere with state penal laws will be honored only if deliberate and unequivocal. Gilbert v. Minnesota, 254 U.S. 325 (1920) ; Halter v. Nebraska, 205 U.S. 34 (1907) ; Presser v. Illinois, 116 U.S. 252 (1886) ; Cohens v. Virginia, 19 U.S. (6 Wheat.) 120, 198 (1821).

Moreover, intent to exclude state action will not be presumed if federal authority under a statute of wide potential application is infrequently exercised. See Atlantic C.L. R.R. v. Georgia, 234 U.S. 280, 294 (1914); cf. Savage v. Jones, 225 U.S. 501,533 (1912). Federal prerogative under $\$ 605$ has only once been utilized. See note 2 supra.

41. Rochin v. California, 342 U.S. 165, 173 (1952) ; Brown v. Mississippi, 297 U.S. 278, 285 (1936) ; Adams v. New York, 192 U.S. 585, 599 (1904) ; Fong Yue Ting v. United States, 149 U.S. 698, 729 (1893); 1 WIGMORE, EVIDENCE $§ 6 e$ (3d ed. 1940) (collecting cases). But see Bepanti v. United States, 355 U.S. 96 (1957) (dictum); Schwartz v. Texas, 344 U.S. 199, $202^{\circ}$ (1952) (dictum) ; ef. Donnelly, Comments and Caveats, at 810 n.60.

42. Schwartz v. Texas, supra note 41 , at 202-03 (collecting state cases).

-43. Regulation of interstate railroads has been pre-empted by the federal government under the commerce power. See Southern Pac. Co. v. Arizona, 325 U.S. 761 (1945). Yet nonemployees regularly recover damages in state civil suits against interstate railroads. See, e.g., Henry v. Pennsylvania R.R., 368 Pa. 596, 84 A.2d 675 (1951). See also Sher- 
clude state control of such broadcasts. ${ }^{44}$ Consequently, those provisions of the Pennsylvania and Illinois acts which define civil remedies for wiretapping would be untouched by decisions holding the criminal proscriptions invalid. If a civil remedy does not have a deterrent effect equivalent to that of a criminal sanction, it would certainly provide more protection than the unenforced federal act. ${ }^{45}$ And while state circumvention cannot restrict wiretapping by federal officers, even nonexcluded state acts may not be valid if so applied.46

Since wiretap control is a subject of continued debate and conflicting conclusions, ${ }^{47}$ it appears a particularly appropriate field for local experimentation. Axiomatic to a defense of wiretapping is the necessity of such activity to effective law enforcement. 48 But the capacity of modern police to enforce the laws without this aid has rarely been tested..$^{49}$ Once construed or amended to exempt federal officers acting in pursuit of federal law, the Pennsylvania and Illinois statutes, if unhampered by needless constitutional obstructions, may thus provide a basis for factual rather than hypothetical resolution of the wiretapping dilemma.

lock v. Alling, 93 U.S. 99 (1876) (pre-emptive congressional safety regulations on navigable waters do not bar liability under a state wrongful-death statute).

But Congress can replace the local right of action with specific federal statutory remedies precluding the local cause. See, e.g., New York Cent. R.R. v. Winfeld, 244 U.S. 147 (1917) (Federal Employer's Liability Act pre-empts cause of action under comparable state laws).

44. See, e.g., Shor v. Billingsley, 4 Misc. 2d 857, 158 N.Y.S.2d 476 (Sup. Ct. 1957) (cause of action allowed for libel) ; Allen B. Dumont Laboratories v. Carroll, 184 F.2d 153 (3d Cir. 1950), cert. denied, 340 U.S. 929 (1951) (Communications Act pre-empts interstate television regulation).

45. See note 2 supra.

46. See note 21 supra and accompanying text.

47. N.Y. Times, April 13, 1958, $\S$ L, p. 58 , col. 1 ; id. Dec. 15,1957 , § 4, p. 7, cols. $1-4$; Rosenzweig, supra note 2; Donnelly, Comments and Caveats. The number of congressional attempts to amend $\S 605$ testify to the controversial nature of the issue. See Westin, Analysis and Proposal, at 180-81 $\mathrm{nn} .71 \& 72$.

48. See Rogers, supra note 1 (collecting authorities).

49. Mr. Justice Frankfurter, dissenting in On Lee v. United States, 343 U.S. 747, 761 (1952), noted that although wiretapping by federal agents was not countenanced by United States Attorney Henry L. Stimson, his administration in the Southern District of New York was eminently successful. 